\title{
ENCONTROS ENTRE 0 RURAL E 0 URBAN0: OCUPAR, PRODUZIR E PRESERVAR NA BACIA DO RIO RATONES
}

\section{Carolina Dal Soglio (UFSC); \\ Themis da Cruz Fagundes, Dra. (UFSC)}

\section{INTRODUÇÃO}

Terra, trabalho e teto foram as motivações que levaram cerca de 60 famílias a ocupar um terreno às margens da SC-401, na altura do bairro ratones, no dia 16 de dezembro de 2013, Em Florianópolis (SC). Em abril já se contava com 725 famílias cadastradas, sendo considerada a maior ocupação rururbana do Estado de Santa Catarina (MACHADO, 2013).

O Trabalho "Encontros entre o Rural e o Urbano" propôs a implantação de um parque voltado à praticas agroecológicas e um assentamento da reforma agrária no terreno ocupado pela Comuna Amarildo, como forma de proteger o território e a bacia hidrográfica do Rio Ratones. Foi resultado de vivências possibilitados pelo AMA (Atelier Modelo de Arquitetura) e pela Comuna Amarildo. caráter rural junto ao urbano, em busca de territórios mais sustentáveis, que contribuam para a questão da moradia digna, do direito à cidade e da conservação dos recursos naturais.

\section{PARQUE AGROECOLÓGICO NA BACIA DO RIO RATONES}

Ao final do século $X X$, as áreas agrícolas e naturais deixaram de ser vistas somente como um vazio suscetível de ser ocupado ou explorado, mas como um espaço tão importante quanto o urbano, a ser preservado (BEL, 2015). Por meio de um parque agroecológico, vislumbra-se a possibilidade de encontros entre o campo e a cidade que beneficiem a população da região.

Figura 01: Proposta de espacialização do Parque Agroecológico

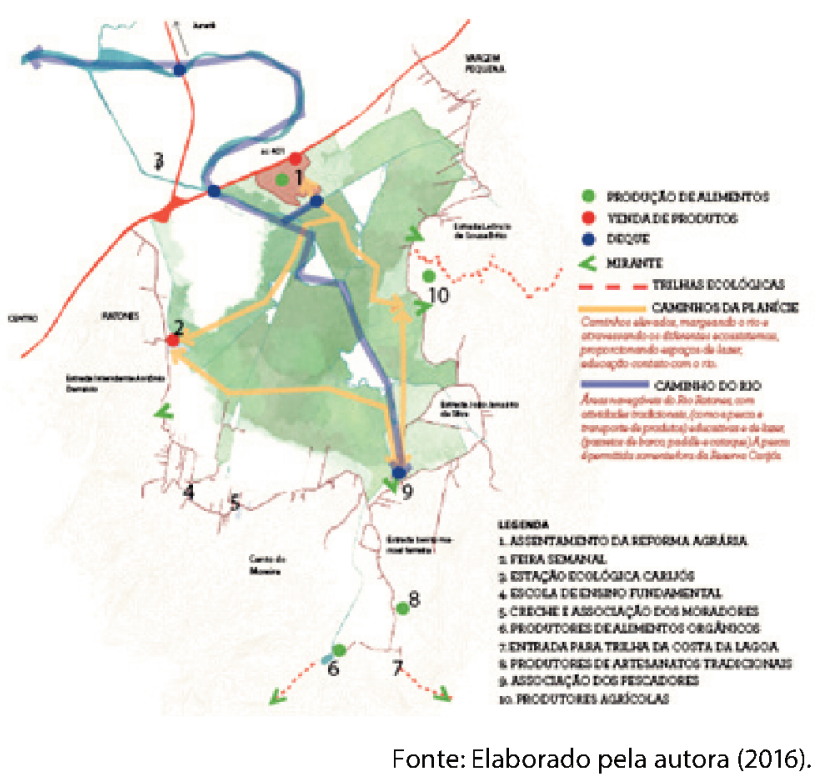

3. ASSENTAMENTO DA REFORMA AGRÁRIA

$O$ projeto do assentamento destina-se a 70 famílias, com espaços de produção de alimentos para sua soberania alimentar, para a produção e o beneficiamento de alimentos, para comercialização dos produtos e para os equipamentos comunitários.

Além das habitações e das áreas de produção, o assentamento deve contar com áreas de administração para cooperativas, creches e áreas de preservação ambiental.

Figura 02: Zoneamento do Assentamento

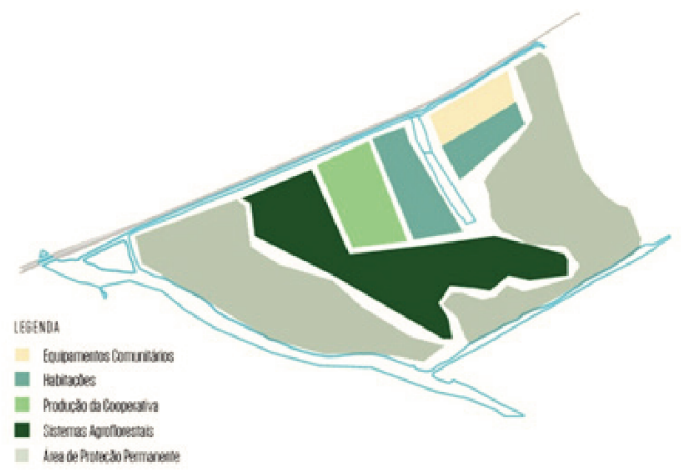

Fonte: Elaborado pela autora (2016) 
Estabeleceu-se uma gradação desde a entrada: Os equipamentos comunitários mais próximos a SC-401, seguidos pela moradia e depois pelas áreas de produção. Os sistemas Agroflorestais conformam uma zona de amortecimento para as Áreas de Proteção Permanente.

Figura 03: Equipamentos comunitários
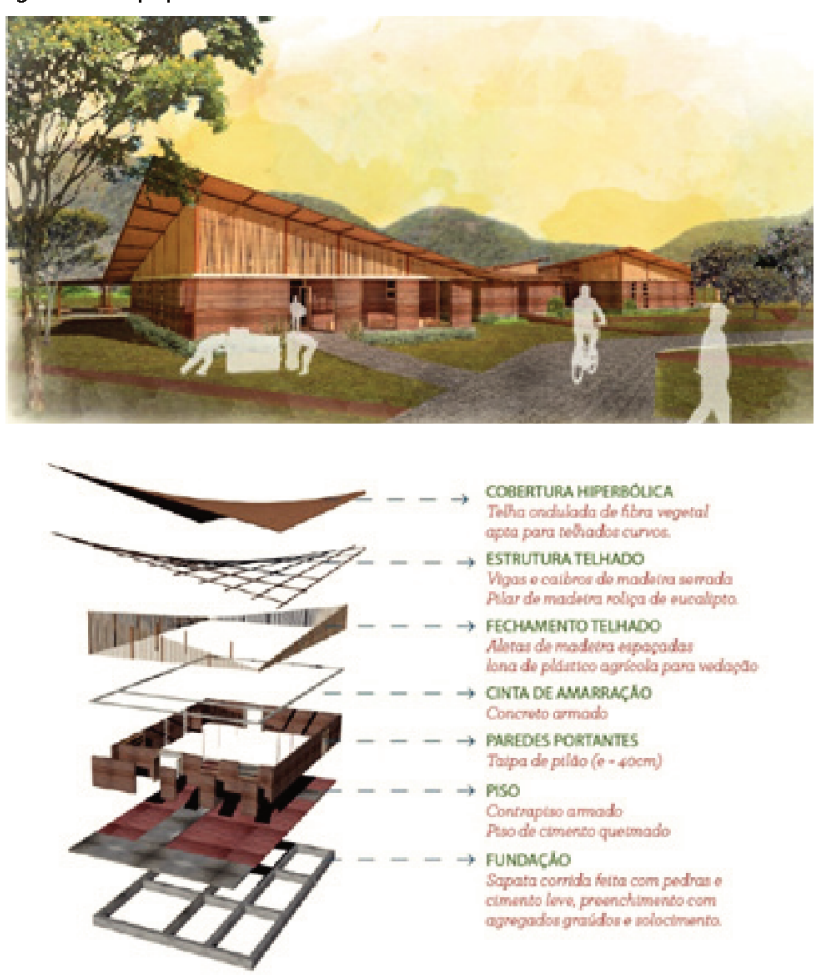

Fonte: Elaborado pela autora (2016).

Para as edificações foram consideradas as técnicas de construção com terra de taipa de pilão e adobe. Estas técnicas são possíveis de serem realizados em mutirão pela própria comunidade, utilizam recursos locais e naturais e apresentam baixo impacto ambiental. A taipa de pilão é uma técnica antiga, onde a terra crua é comprimida em várias camadas, até formar uma parede compacta e espessa, com alta inércia térmica, fazendo com que o calor demore a entrar e a sair da edificação.

Aprender a lidar com sistemas complexos como são as dinâmicas do ser humano sobre o espaço é essencial para os Arquitetos e Urbanistas, para que seja possível modificar o processo de produção atual e encontrar novas maneiras de relacionar-se com os recursos que a terra nos oferece.

\section{REFERÊNCIAS}

MACHADO, Paulo Pinheiro. Os motivos rurais de uma invasão urbana. 15/03/2014. Diário Catarinense Online.
SISU, Seminário Internacional de Investigación en Urbanismo. Junho, 2015. Montevidéu, Uruguai. p. 13 a 15.

WBEL, Joaquín Sabaté. Retos del Proyecto Territorial. ANAIS do VII. 